\title{
Revision of Potamogeton fossils from the Most Basin and their palaeoecological significance (Early Miocene, Czech Republic)
}

\author{
VASILIS TEODORIDIS
}

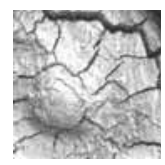

\begin{abstract}
Only 37 incomplete endocarps and fragments of Potamogeton wiesaensis Kirchheimer from the Nástup-Tušimice Mine and cores of KU 115 and MR 59, and one incomplete leaf assigned as Potamogeton praenatans Knoll from the Bílina Mine (horizon No. 1) are described from the Most Basin. These samples studied here stratigraphically belong to the Holešice, Libkovice and Lom members of the Most Formation. According to the analysis of Potamogeton autecology and the floristic composition of the horizon No. 1, the fossil taxa can be interpreted as elements of an aquatic and reed vegetation. - Key words: leaves, endocarps, Potamogeton, palaeoecology, Early Miocene, Most Basin.
\end{abstract}

TeOdORIDIS, V. 2007. Revision of Potamogeton fossils from the Most Basin and their palaeoecological significance (Early Miocene, Czech Republic). Bulletin of Geosciences 82(4), 409-418 (4 figures, 1 table). Czech Geological Survey, Prague. ISSN 1214-1119. Manuscript received January 2, 2007; accepted in revised form April 11, 2007; issued December 31, 2007. • DOI 10.3140/bull.geosci.2007.04.409

Vasilis Teodoridis, Charles University in Prague, Faculty of Education, Department of Biology and Environmental Education, M.D. Rettigové 4, 11639 Prague 1, Czech Republic; vasilis.teodoridis@pedf.cuni.cz.

Occurrences of Potamogetonaceae are extremely rare in the area of the Most Basin. This study focuses on a revision and modern evaluation of leaf and carpological material previously collected by Č. Bůžek (from 1961 to 1962) and others and its implication for the palaeoecological significance. E. Knobloch gave an overview about the Neogene and Early Quaternary Potamogeton fossils from Moravia and Slovakia including short comments on Czech specimens (Knobloch 1977, pp. 30, 31).

The family Potamogetanaceae contains perennial or rarely annual floating-leaved or submersed glabrous herbs growing in fresh or brackish waters, sometimes stranded by receding water levels (Haynes et al. 1998). The systematics of the Potamogetonaceae is contentious and usually two or three genera are determined; Potamogeton L., Groenlandia J. Gay and Coleogeton (Rchb.) Les \& R.R. Haynes (Les \& Haynes 1996), the latter newly reassigned as Stuckenia Börner (Haynes \& Hellquist 2000); see Les \& Haynes (1995), Haynes et al. (1998). The foliage of Potamogeton L. occurs as submersed or floating leaves in alternate to subopposite position. The floating leaves have a firmer texture, mostly petiolate, rarely subsessile, elliptic to ovate in outline, subulate to obtuse at apex and cuneate to rounded or cordate at base, leaf margins entire, venation parallelodromous to acrodromous with 1-51 veins. The submersed leaves are sessile or petiolate, linear to orbicular in outline, subulate to obtuse at apex and cuneate to perfoliate at base, leaf margins entire or serrate, rarely crimped, venation parallelodromous to acrodromous with 1-35 veins.

Fruits of Potamogeton are best considered as a drupe having a membranous exocarp, fleshy mesocarp and stony endocarp. Potamogeton fruits are born laterally on a fruiting spike usually in whorls of four, with from one to over 20 whorls per spike. Each fruit is sessile, attached at the base of the ventral (adaxial) margin and contains a single, pendulous, campylotropous ovule. The fruits are D-shaped to subovate in lateral view, bisymmetrical and strongly bilaterally flattened in the plane of symmetry. They are narrowly ovate in transverse section (Collinson 1982, p. 84); see Fig. 4F-H. The seed is equally lobed and curved around an internal process from the lateral and ventral faces of the fruit wall. A rounded depression is present on the external faces of the fruit in the position of this process. A germination valve occupies the entire dorsal margin and extends around the base of the fruit.

\section{Geological settings}

The Most Basin is located between the Doupovské hory Mts. and the České středohoři Mts. in northwestern Bohemia and genetically belongs to the tectonic system of the Eger Graben. The basin fill spans the time interval from the Oligocene to late Early Miocene. These sediments belong 


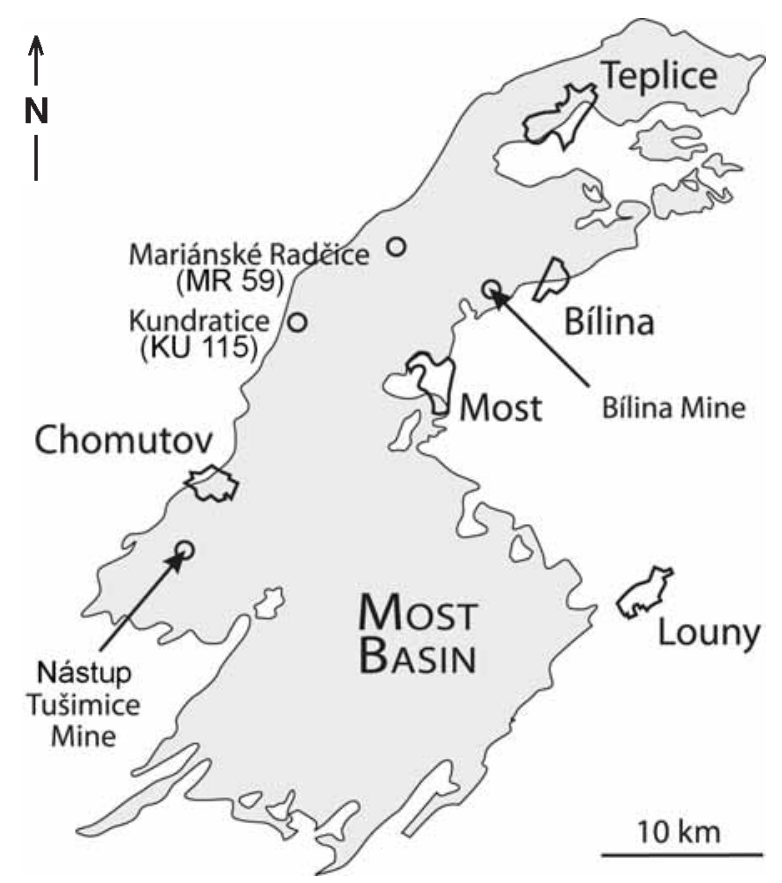

Figure 1. Geographical position of the studied localities and cores in the area of the Most Basin.

stratigraphically to the Střezov Formation and the Most Formation (sensu Domácí 1977). The volcanic rocks of the Střezov Formation consist of magmatic weathered lava flows related to volcanogenic deposits. These sediments are also mixed with weathered residua of older rocks from wider surroundings, and had been transported within a river system of the so-called "Hlavačov Gravel and Sand" (Váně 1985, Rajchl \& Uličný 2005). This river system probably persisted during depositing of the first Duchcov Member of the Most Formation (e.g., Teodoridis 2004), called previously and/or informally the Underlying Formation (sensu Elznic 1973). The overlying Holešice Member corresponds to a sedimentary setting of the Main Coal Seam that has been interrupted by irregularly distributed sandy-clayey bodies of the Žatec Delta (e.g., Václ \& Malkovský 1962, Rajchl \& Uličný 2005) and the Bílina Delta (e.g., Mach 2002). These delta bodies are situated in the SE part of the basin. The deposition of the Libkovice Member, i.e. the Overlying Formation sensu Elznic (1973), continued the sedimentary process in the Most Basin. These sediments, mostly clay or claystone spread over the mire covering the previous "coal" layers. A coal-forming vegetation re-appears in the uppermost part of the Most Formation and has delimited the range of the Lom Member sensu Domácí (1977), i.e. the Lom Formation of Elznic (1973). More details about the geological situation can be found in Malkovský et al. (1985), Mach (2002), Rajchl \& Uličný (2005), Teodoridis \& Kvaček (2006), etc.

The core MR 59 (Mariánské Radčice) offers the most abundant material (29 specimens) from two fossiliferous levels; a coal horizon (depth 48-50 m) and a light brown clayey horizon with plant fragments (depth 49.8-50 m) (Jirotka 1976, Kvaček \& Bůžek 1982). These horizons belong to the coal seam of the Lom Member (Figs 1, 2).

The core KU 115 (Kundratice) has yielded only one endocarp from a coal-clayey horizon (depth 97.0-98.0 m) corresponding to the uppermost part of the Libkovice Member (Figs 1, 2). The endocarps from the Nástup-Tušimice Mine ( 7 specimens) are bound in a brown clayey horizon that contains also a rich fish fauna (Oberhelová 1983, p. 7) and belongs to the uppermost part of the Holešice Member (Kvaček 2006); Figs 1, 2. Similarly, the studied leaf material is bound to a sandy-clayey horizon (No. 1) from the Bílina Mine (Bůžek et al. 1992), corresponding to the lower part of the Libkovice Member (Figs 1,2).

\section{Material and methods}

The fossil carpological material is compressed, carbonaceous and three-dimensionally preserved and was obtained from the cores by washing. It is housed in the palaeontological collection of the National Museum, Prague (NM - 37 specimens). The incomplete leaf (DB 1-55) is from horizon No. 1 (Bílina Mine) and is housed in the palaeontological collection of the Severočeské doly, a.s., Doly Bílina (DB). The comparative fossil leaf material from the locality Ležáky (Most Basin) originally assigned (erroneously) to Potamogeton (Hurník in Hurník \& Knobloch 1966) is housed in the geological collection of the Regional Museum in Most (MM). Comparative extant material was obtained from the herbaria of the Charles University, Prague (PRC), National Museum, Průhonice (PR) and W. Szafer Institute of Botany, Polish Academy of Sciences, Krakow (KRA). The specimens were examined and detailed studies and observations made using a binocular microscope and a $15 \mathrm{kV}$ Jeol JSM - 6380 LV scattered electron microscope (SEM) used at the Institute of Geology and Palaeontology, Faculty of Science, Charles University in Prague. One specimen of Potamogeton wiesaensis Kirchheimer (G 8537) from the Nástup-Tušimice Mine was studied for the structure of the testa. A mechanically isolated testa was washed in water and briefly macerated in Schulze solution, followed by rinsing in weak potassium hydroxide solution $(\mathrm{KOH})$, then water, and embedded in glycerine directly on the microscope glass, after a few minutes covered with a cover slide and sealed with nail polish.

Currently accepted morphological terminology follows Stearn (2004) for leaves and Velichkevich \& Lesiak (1996) for fossil endocarps. Symbols and abbreviations for distinguishing vegetation storeys in environmental reconstruction and climatic parameters are: E1 (herbs and vines), E2 (shrubs and lianas), E3 (trees under $25 \mathrm{~m}$ high) and E4 (trees over $25 \mathrm{~m}$ high). 


\section{Description}

Potamogetonaceae Dumortier

\section{Potamogeton L.}

Potamogeton wiesaensis Kirchheimer Figure 3A-P

1942 Potamogeton? n. sp., Kirchheimer, p. 443, fig. 18.

1957 Potamogeton wiesaensis Kirchheimer, p. 271, 354, pl. 13, fig. $61 \mathrm{a}-\mathrm{c}$.

1985 Potamogeton sp., Friis, p. 74, pl. 22, figs 15, 16 (Fasterholt flora, Middle Miocene).

2003 Potamogeton wiesaensis Kirchheimer. - Czaja, p. 95, pl. 19 , figs 6,7 .

2003 Potamogeton wiesaensis Kirchheimer. - Teodoridis, p. 25 , pl. 7 , figs $3,4,10$, non 9 , pl. 8 , figs 8,9 .

Description. - Endocarps one-loculed with a strongly curved seed cavity, oval to rounded in outline (Fig. 3E, I), robust and thick-walled, often laterally compressed, 1.74-(2.61)-2.89 mm long and 1.25-(1.95)-2.3 mm broad, maximal thickness in transversal plane 1.02-(1.06)-1.12 mm; base rounded, basal wart rarely incomplete preserved (Fig. 3B), apex obtuse including indistinct fragmentary acute base of style (Fig. 3E, J), lateral sides markedly convex with distinct central depression, oval to rounded in outline (Fig. 3B), 0.44-(0.5)-0.63 mm long and $0.25-(0.34)-0.45 \mathrm{~mm}$ broad, rarely perforated in the middle (Fig. 3G), ventral side straight or concave (Fig. 3L), rarely convex (Fig. 3I), sometimes with distinct mouth of central depression (Fig. 4L); germination valve extending from base to apex (no "shoulder" in apical part), bordered by the distinct keel (Fig. 3H, K), upper surface more or less smooth. Anatomical structure of the germination valve is composed of two parts: outer multiseriate layer of tetragonal to polygonal sclereids, often compressed, 11.84-(19.47)-23.68 $\mu \mathrm{m}$ long and 11.84-(20.79)-27.63 $\mu \mathrm{m}$ broad (Fig 2Na) and inner uniseriate layer is built of elongated orthogonal sclereids, 23.68-(27.63)-34.21 $\mu \mathrm{m}$ long and 7.89-(9.87)-11.84 $\mu \mathrm{m}$ broad (Fig. 3Nb). Cracked endocarps show upper surface of seed testa (Fig. 3F). Seed campylotropous, cashew-shaped, rounded on both ends (Fig. 4O); micropyle indistinct, chalaza present at the rounded end (Fig. 4P). Seed testa reticulate, only outer thin layer of the regular, tetragonal, thin-walled cells preserved, 22.37-(45.3)-57.9 $\mu \mathrm{m}$ long and 11.84-(15.57)-21.1 $\mu \mathrm{m}$ broad (Fig. 3Nc, P).

Discussion. - Several species of Potamogeton L. appear in a period from the Late Oligocene to the Early Miocene in West and Central Europe. The delimitation of species based on the fruit morphology is problematic even in the case

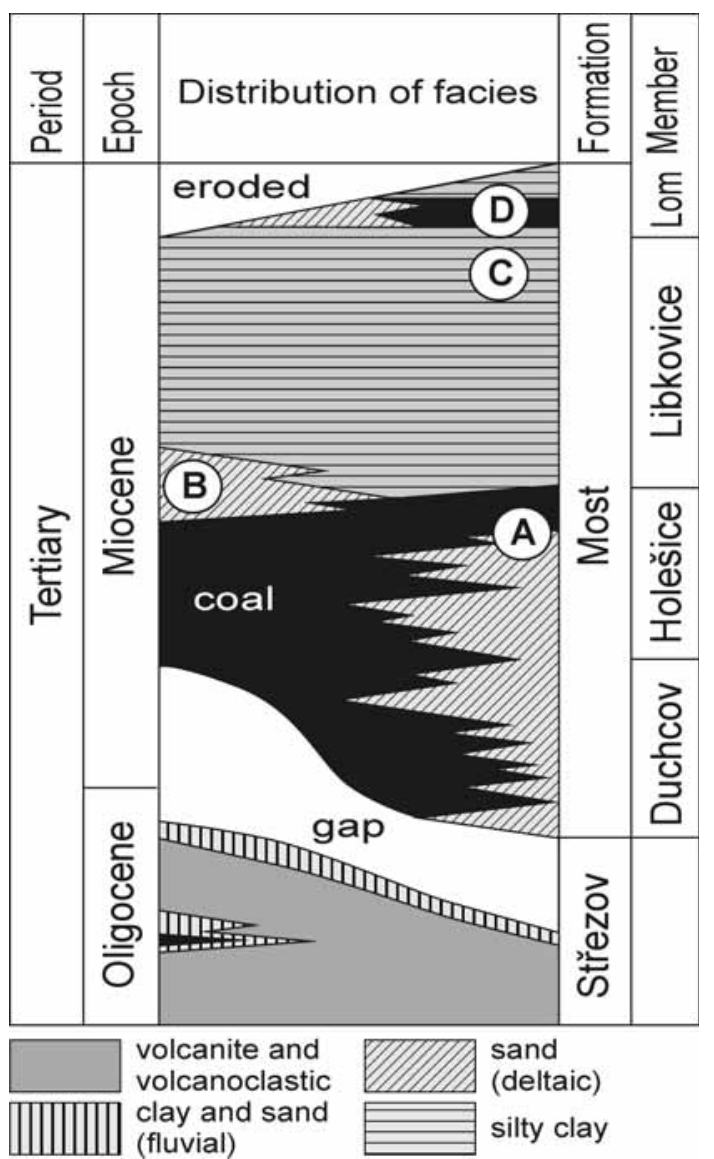

Figure 2. Stratigraphical position of the studied localitiea and cones in the Most Basin. Litostratigraphy modified after Mach (2002). Symbols: A - the Nástup-Tušimice Mine, B - the Bílina Mine (horizon 1), C-core KU 115 (Kundratice), D - core MR 59 (Mariánské Radčice).

of complete endocarps but it is almost impossible when using their fragments. Potamogeton nochtensis Mai, $P$. heinkei Mai and $P$. wiesaensis Kirchheimer are known from Early Miocene localities in Middle Europe (Saxony, Lusatia; e.g., Czaja 2003; Mai 1999, 2000) and morphologically correspond to the studied material at first view. These taxa are more or less identical in shape and size but differ in other details. Mai (1987, p. 117, pl. 9, figs 5, 6, text-fig. 4a-d) described endocarps of $P$. nochtensis Mai and based this taxon on the holotype from the locality Nochten. However, it is necessary to point out that this taxon has been firstly described and typified by Holý (1976, p. 10, pl. 3, figs 1-10) as P. nochtensis Mai sp. nov. "(hoc loco)" from the locality Kristina including determination of holotype G 4295 (NM); see Gregor (1982, p. 127). The endocarps of $P$. nochtensis possess suddenly narrowing apices into the strong style and non-keeled germinal valves in the apical area, i.e. having a "shoulder" sensu Velichkevich \& Lesiak (1996). The endocarps of this taxon are closely related to those of Potamogeton minutus Dorofeev (1963, p. 103, pl. 8, figs 7-16) based on the material from 
the locality Tchernolutchej (Late Miocene, Siberia), but differs in the smaller size and distinctly keeled germination valves of the endocarps. Recently, further records of $P$. $m i$ nutus were described from other European localities of the Middle and Late Miocene age, e.g., Klettwitz (Mai 2000, p. 29). Comparable endocarps of Potamogeton manykinii Dorofeev (1977, p. 375, text-figs 5-8) with smaller "shoulders" are also known from the Early Miocene of Lusatia, e.g., Hartau, Zittau, Spremberg (Mai 1999, p. 31) but they strongly differ in the dentate keel of the germination valves and a distinct $\mathrm{S}$-shaped sinus on the ventral side. Potamogeton heinkei Mai was defined on the carpological material from the locality Hartau (Mai 1960, p. 78, pl. 4, figs 1-6). These endocarps occur in association with the above-mentioned $P$. nochtensis in the locality Kristina Mine, Hrádek upon Nisa (Holý 1974, 1976), and their delimitation is in some cases unclear. A clue could be the absence of the "shoulder", i.e. the fully developed keel of the germination valves in P. heinkei. Friis (1985) extended the morphological description of $P$. heinkei and gave information about the endocarp wall and inner germination valve structures, based on the material of the Fasterholt, Damgaard and Søby floras from Demark (Middle Miocene). She described also several endocarps as Potamogeton sp. from the Fasterholt flora. This material is well comparable to $P$. heinkei in general morphology, only slightly smaller, but differs strongly in the inner structure of the germination valve, which is, however, identical to the studied material from the Most Basin (Fig. 3N). Another similar species of Potamogeton - P. wiesaensis Kirchheimer is based on carpological material from the locality Wiesa (Kirchheimer 1957 , p. 271, pl. 13, fig. 61a-c). These endocarps have usually been presented as bigger and more robust than those of $P$. nochtensis and $P$. heinkei but with the respect to length and breadth parameters, they show a mutual overlapping in the intervals of 1.5-2.1 mm (length) and 1.0-1.5 (breadth); see Holý (1974, 1976), Mai (1960, 1987), Czaja (2003), Teodoridis (2003). However, endocarps of P. wiesaensis are typical of markedly arched (convex) thick-walled lateral sides including deep or perforated central depressions and distinctly keeled germination valves. Similar endocarps but more slender with bigger central depressions on lateral sides were described from the Early Miocene of western Siberia as Potamogeton dravertii Dorofeev (1963, p. 25, fig. 6/1-5). Besides the above-mentioned taxa, there are some others occurring during the Late Oligocene-Early Miocene period that differ in size, e.g., P. tenuicarpus C. et E.M. Reid (1910, p. 173, pl. 16, figs 53, 54) or in the presence of spiny keel of germination valve in $P$. pygmaeoides Mai (1987, p. 117, pl. 9, figs 7-9, text-fig. 5a-d) and P. ornatus Dorofeev (1963, p. 21, fig. 3/1-12).

The above-described carpological material from the cores KU 115, MR 59 and the Nástup-Tušimice Mine shows more or less uniform morphological pattern and corresponds to the presented definition of Potamogeton wiesaensis Kirchheimer. The endocarps vary in size contrary to the type material from the locality Wiesa. Bůžek \& Holý (1964, p. 124 , pl. 6 , fig. 16 , text-fig. $2 / 8$ ) described three complete and two fragmentary specimens as Potamogeton sp. from the cores Hš 4 (Hošnice), Ot 27 (Otvice), Pe 21 (Pesvice) and VP 14 (Vysoká Pec). Unfortunately, this material is missing. The published figures and the detailed description show a totally different morphological pattern compared to the studied material. The published specimens are twice as big and differ in the rugulose to short spinulose upper surface. The assignment of this material to Potamogeton is uncertain and less probable. These facts corroborate the preliminary statement of Bůžek in Knobloch (1977, p. 31), who also excluded the affinity with Potamogeton. Bůžek et al. (1976, p. 110) described one endocarp as Potamogeton sp. from the locality Markvartice (Late Oligocene, České středohoří Mts.). The endocarp is completely different from

Figure 3. A-M - Potamogeton wiesaensis Kirchheimer. - A - complete endocarp with slightly concave ventral side and fragment of style, G 8343 (NM), Mariánské Radčice, core MR 48.0-49.3 m, scale bar $500 \mu \mathrm{m}$. • B - complete endocarp showing rounded central depression on its lateral side, basal wart (arrow) and distinctly convex lateral sides, G 8518 (NM), Mariánské Radčice, core MR 59/49.8-50.0 m, scale bar 500 $\mu$ m. • C - incomplete endocarp with distinct germination valve, G 8519 (NM), Mariánské Radčice, core MR 59/49.8-50.0 m, scale bar 500 $\mu$ m. • D - incomplete endocarp in dorsal view showing germination valve and its keel, G 8532 (NM), scale bar $500 \mu \mathrm{m}$. $\bullet$ E - cracked complete endocarp with fragment of style showing striated surface of seed (arrow), G 8521 (NM), Mariánské Radčice, core MR 48.0-49.3 m, scale bar $500 \mu \mathrm{m}$. • F - detail of Fig. 3E showing striated surface of seed in detail, scale bar $500 \mu \mathrm{m} . \bullet \mathrm{G}$ - incomplete endocarp with perforated central depression on its lateral side, G 8525 (NM), Mariánské Radčice, core MR 59/49.8-50.0 m, scale bar $500 \mu \mathrm{m}$. $\bullet \mathrm{H}$ - complete endocarp with distinctly keeled germination valve (arrow) and markedly convex on its lateral sides, G 8517 (NM), Mariánské Radčice, core MR 59/48.0-49.3 m, scale bar 500 mm. • I - complete endocarp of rounded outline, G 8338 (NM), Kundratice, core KU 115/97.0-98.0 m, scale bar $500 \mu \mathrm{m}$. • J - complete endocarp with fragment of style and distinct keeled germination valve, G 8534 (NM), Nástup-Tušimice Mine, scale bar $500 \mu \mathrm{m}$. $・ \mathrm{~K}$ - detail of Fig. 3J in dorsal view showing germination valve and its keel (arrow), G 8534 (NM), scale bar $500 \mu \mathrm{m}$. $\bullet \mathrm{L}$ - incomplete endocarp with distinct concave ventral side and mouth of central depression (arrow), G 8522 (NM), Mariánské Radčice, core MR 48.0-49.3 m, scale bar $500 \mu \mathrm{m}$. $\bullet \mathrm{M}$ - longitudinal cross-section of endocarp showing section of cashew-shaped seed cavity (a) and one rounded seed end (b), G 8553 (NM), Nástup-Tušimice Mine, scale bar $500 \mu \mathrm{m}$. $・ \mathrm{~N}$ - detail of Fig. 3M, inner structure of germination valve and seed testa: composed of outer several layers of elongated and polygonal sclereids (a), inner uniseriate layer built of elongated orthogonal sclereids (b), reticulate seed testa composed of one outer thin layer of regular, tetragonal, thin-walled cells (c), G 8536 (NM), Nástup-Tušimice Mine, scale bar $200 \mu$ m. • O, P - Potamogeton wiesaensis Kirchheimer, macerated seed testa G 8537 (MN), Nástup-Tušimice Mine. • O - testa of cashew-shaped seed, scale bar 500 um. • P - detail of Fig. 3O, chalaza and reticulate pattern of seed testa composed of regular, tetragonal, thin-walled cells, scale bar $100 \mu \mathrm{m}$. 

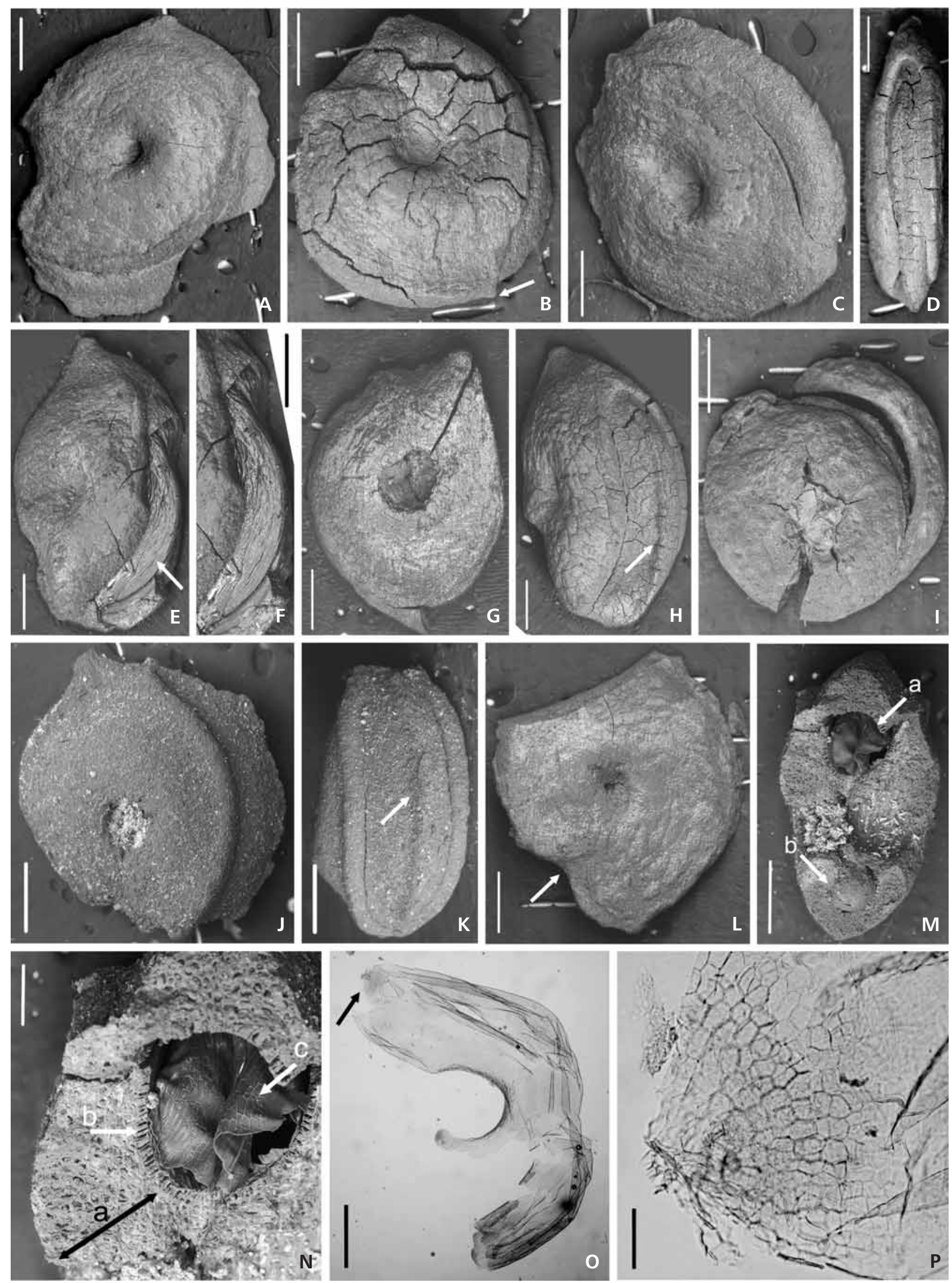
all other species of Potamogeton in the Tertiary and should be recognized as a new species.

\section{Potamogeton praenatans Knoll}

Figure 4A-C

1903 Potamogeton praenatans Knoll, p. 272, pl. 10, figs 1-4.

?1969 Potamogeton martinianus Sitár, p. 112, pl. 22, fig. 4, pl. 23, figs 3, 4, pl. 27, figs 1 , 2, text-fig. 2 .

?1991 Potamogeton martinianus Sitár. - Kovar-Eder \& Krainer, p. 746, pl. 7, figs 4-6, 10, 11.

Description. - Incomplete leaf oblong in outline, $33.5 \mathrm{~mm}$ long and $16.2 \mathrm{~mm}$ broad, apex not preserved, base cuneate, narrowed into thick fragmentary petiole $(5.74 \mathrm{~mm}$ broad in its upper part), margin entire; venation acrodromous with thicker midrib and 2 lateral pairs of thick primary veins (leaf 5-veined), interspaced at the distance of $0.15 \mathrm{~mm}$ (in central part of the leaf lamina) by thinner lower-order lateral veins, originated from the midrib (Fig. 4C), venation of higher orders not preserved.

Discussion. - The leaf is morphologically similar to Potamogeton praenatans Knoll described by Knoll (1903) from the locality Windisch-Pöllau near Gleisdorf (Austria, Pannonian). These fossils represent submersed and floating leaves. The studied leaf is interpreted as the submerse type due to its oblong outline and the character of the leaf base and petiole. Hurník in Hurník \& Knobloch (1966) noticed occurrences of Potamogeton cf. praenatans Knoll from the locality Ležáky (Most Basin). However, these leaves (Fig. 4D, E) match better the recently defined morphospecies of Smilacinites ungeri Kvaček in Kvaček et al. (2004, p. 34, figs 20/1-4, 21/1-7) rather than Potamogeton. Both taxa differ mainly in the leaf shape and venation, which in Smilacinites is characterized by three orders of lateral veins and the typical oblique transversal connective veins (Fig. 4E). Kvaček \& Bůžek (1982, p. 17) recorded the rare occurrence of "Potamogeton" leaves in the delta facies of the Bílina Mine. Generally leaves of Potamogeton are rare in the Tertiary settings. A submersed leaf of Potamogeton bruckmanni A. Br. is noted from the locality Öhningen (Switzerland) by Braun (Braun in Stizenberger 1851, p. 76) and figured by Heer (1855, p. 102, pl. 47, fig. 7). Knoll (1903) supposed its affinity to the family Alismataceae based on the venation (Knoll 1903, p. 271). Besides the mentioned species P. praenatans, Knoll (1903) also described other leaves from the locality Andritz near Graz (Austria, Pannonian) as Potamogeton stiriacus Knoll. The leaves can be interpreted as floating leaves and are more or less identical with $P$. praenatans except for the less distinct leaf midribs. Brabenec (1909, p. 64) described leaves and fruits of $P$. geniculatus A.Br. from the localities Břeštany (Early Miocene, Most Basin) and Kučlín (Late Eocene, České středohoří Mts.), leaves of $P$. poacites Ettingsh. from the locality Jehličná (Late Eocene, Sokolov Basin) and leaves of $P$. schrotzburgensis Heer from the locality Kundratice (Early Oligocene, České středohoří Mts.). Unfortunately, this material is missing. Similarly, Němejc (1967, pp. 16-18) mentioned leaves belonging probably to Potamogeton sp. from the Sarmatian localities Hontianské Vrbice, Nižní Skalník and Krásné upon Hornád (Slovakia). Knobloch (1969a) described one complete leaf as Potamogeton sp. from the locality Žilina near Nový Jičín (Karpatian, Northern Moravia). This sample is different from the above-described $P$. praenatans in having oval shape and high number of primaries (18). Knobloch (1969b) described another leaf material as $P$. wieseri Kov. from the Dukla Mine near Mistřín (Pannonian, Southern Moravia). Sitár (1969) described incomplete leaves as Potamogeton martinianus Sitár from the locality Martin (Sarmatian, Slovakia). This material shows considerable similarities in shape and venation pattern with the floating leaves of $P$. praenatans. Therefore, the epitethon "praenatans" should be given priority. Kovar-Eger \& Krainer (1991) described further Potamogeton leaves from the locality Reith near Unterstorcha (Pannonian, Austria). They showed some similarity in leaf character with the leaf fragment from the Sarmatian flora of the Holy Cross Mts., Poland (Zastawniak 1980, p. 85).

\section{Associated flora}

In addition to the Potamogeton leaf, the horizon No. 1 (Fig. 2) yielded a rich flora with one horsetail, two ferns, two conifers and 40 angiosperm species (Table 1). The composition of this flora is consistent with the general cha-

Figure 4. A-C-Potamogeton praenatans Knoll. $•$ A - submersed leaf, DB 1-55 (DB), Bílina Mine (horizon No. 1), scale bar 10 mm. $\bullet$ B - detail of leaf base and petiole, DB 1-55 (DB), Bílina Mine (horizon No. 1), scale bar $5 \mathrm{~mm}$. $\bullet$ - detailed venation of leaf lamina with originating of lower-order lateral vein from midrib (arrow), DB 1-55 (DB), Bílina Mine (horizon No. 1), scale bar 5 mm. • D, E - Smilacinites ungeri Kvaček. • D - leaf, G/Pa 355 (MM), Ležáky, scale bar $10 \mathrm{~mm}$. E - detailed venation of leaf lamina, G/Pa 355 (MM), Ležáky, scale bar 5 mm. • F - Potamogeton polygonatus Pour, Almquist 1911 (KRA), S Zwecia, Poland, fructification, scale bar 5 mm. • G, H - Potamogeton polygonatus Pour, Schepping 1889 (KRA), Lauchhamer, Germany, endocarps, scale bar $500 \mu \mathrm{m}$. • I, J - Potamogeton nodosus Poiret, Z. Kaplan 03/203 (PR), Sokoleč, Czech Republic. • I - habit, scale bar 10 mm. • J - detailed venation of leaf lamina with origination of lower-order lateral vein from midrib (arrow), scale bar $5 \mathrm{~mm}$. 

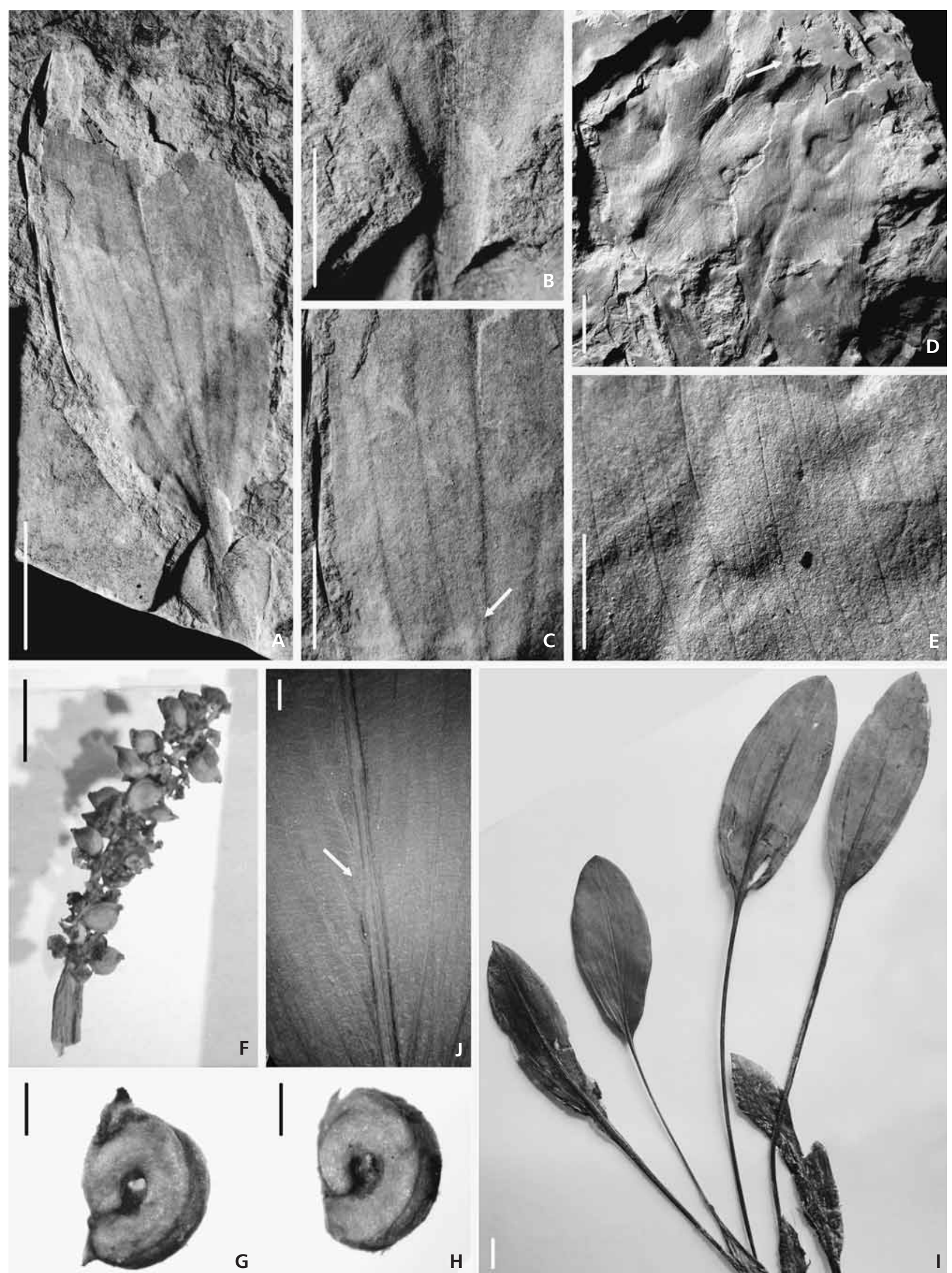

G

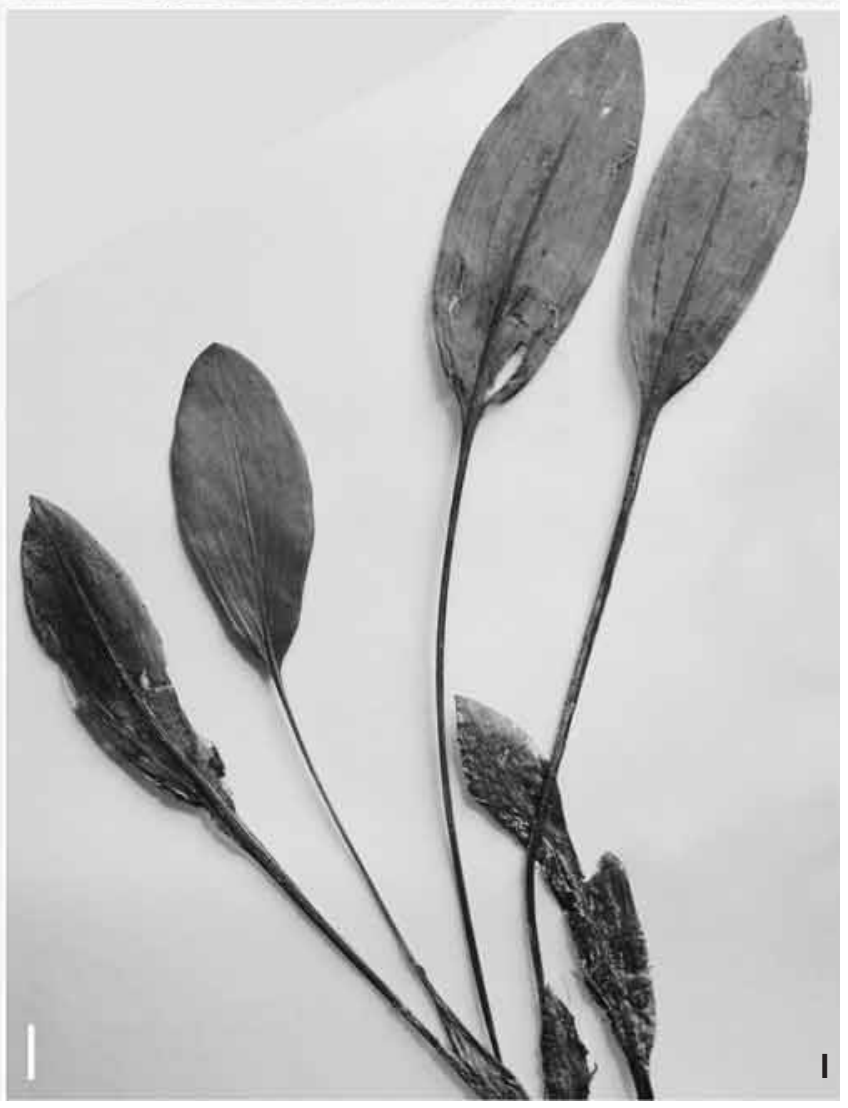


Table 1. Floristic composition of the associated floras from the studied locality and cores in the Most Basin. • Abbreviations: C-cone, F-fruit, L-leaf, $\mathrm{S}$ - seed, Sp - spores, G - associated floras from the studied localities, H - No. 1, I - Nástup-Tušimice, J - KU 115, K - MR 59, O - organ.

\begin{tabular}{|c|c|c|c|c|c|}
\hline \multirow{2}{*}{ Taxa } & \multirow{2}{*}{$\mathrm{O}$} & \multicolumn{4}{|c|}{ G } \\
\hline & & $\mathrm{H}$ & $\mathrm{I}$ & $\mathrm{J}$ & $\mathrm{K}$ \\
\hline$\overline{\text { Acer angustilobum Heer }}$ & $\mathrm{L}$ & $*$ & & & \\
\hline Acer integerrimum (Viviani) Massalongo & $\mathrm{L}$ & $*$ & & & \\
\hline Acer tricuspidatum Bronn sensu Procházka \& Bůžek & $\mathrm{L}, \mathrm{F}$ & $*$ & & * & \\
\hline Alnus gaudinii (Heer) Knobloch \& Kvaček & $\mathrm{L}$ & $*$ & & $*$ & \\
\hline Alnus julianiformis (Sternb.) Z. Kvaček \& Holý & $\mathrm{L}, \mathrm{F}$ & $*$ & & $*$ & \\
\hline Azolla aff. nana Dorofeev & $\mathrm{F}$ & & & & $*$ \\
\hline Azolla aff. rossica Dorofeev & $\mathrm{F}$ & & & & $*$ \\
\hline Azolla aff. ventricosa P. Nikitin sensu Dorofeev & $\mathrm{F}$ & & & & $*$ \\
\hline Berberis cf. berberidifolia (Heer) Palmarev \& Petkova & $\mathrm{L}$ & $*$ & & & \\
\hline Berchemia multinervis (A.Br.) Heer & $\mathrm{L}$ & $*$ & & & \\
\hline Betula sp. & $\mathrm{L}$ & $*$ & & & \\
\hline Carex sp. & $\mathrm{F}$ & & & $*$ & \\
\hline Cercidiphyllum crenatum (Ung.) Brown & $\mathrm{L}, \mathrm{F}$ & $*$ & & & \\
\hline Comptonia difformis (Sternb.) Berry & $\mathrm{L}$ & $*$ & & & \\
\hline Comptonia srodoniowae Friis & $\mathrm{F}$ & & & * & \\
\hline $\begin{array}{l}\text { Craigia bronnii (Ung.) Kvaček, Bůžek \& Manchester/ } \\
\text { Dombeyopsis lobata Ung. }\end{array}$ & $\mathrm{F}, \mathrm{L}$ & $*$ & & & \\
\hline Daphnogene polymorpha (A.Br.) Ettingsh. & $\mathrm{L}$ & $*$ & & $*$ & \\
\hline Decodon gibbosus (E.M. Reid) E.M. Reid in Nikitin & $\mathrm{L}$ & $*$ & & & \\
\hline Diversiphyllum aesculapi (Heer) Bůžek & $\mathrm{L}$ & $*$ & & & \\
\hline Engelhardia macroptera (Brongn.) Ung. & $\mathrm{F}$ & $*$ & & & \\
\hline Equisetum parlatorii (Heer) Schimper & $\mathrm{L}$ & $*$ & & & \\
\hline Faxinus bilinica (Ung.) Kvaček \& Hurník & $\mathrm{L}, \mathrm{F}$ & $*$ & & & \\
\hline "Ficus" truncata Heer sensu Bůžek & $\mathrm{L}$ & $*$ & $*$ & & \\
\hline Glyptostrobus europaeus (Brongn.) Ung. & $\mathrm{L}, \mathrm{C}, \mathrm{S}$ & $*$ & & $*$ & \\
\hline "Juglans" acuminata A.Br. ex Ung. & $\mathrm{L}$ & $*$ & & & \\
\hline Koelreuteria reticulata (Ettingsh.) Edwards & $\mathrm{F}$ & $*$ & & & \\
\hline Laurophyllum pseudoprinceps Weyland \& Kilpper & $\mathrm{L}$ & & & $*$ & \\
\hline Laurophyllum pseudovillense Knobloch \& Z. Kvaček & $\mathrm{L}$ & & & $*$ & \\
\hline Leguminosites sp. div. & $\mathrm{F}$ & $*$ & & & \\
\hline Liquidambar europaea A.Br. & $\mathrm{F}$ & $*$ & & & \\
\hline Mahonia bilinica (Ung.) Kvaček \& Bůžek & $\mathrm{L}$ & $*$ & & & \\
\hline
\end{tabular}

racter of the Bílina Delta floras (see for detail Bůžek et al. 1992, Kvaček et al. 2004, Teodoridis \& Kvaček 2006). The associated floras of the core KU 115 included three conifers and 11 angiosperms and of the core MR 59 contained only four aquatic ferns (Table 1; Teodoridis 2005, Teodoridis \& Kvaček 2006). Similarly, associated flora from the Nástup-Tušimice Mine included only coal forming elements (Table 1; Kvaček 2006, Teodoridis \& Kvaček 2006).

\section{Living relatives}

According to the morphological analysis of the recent fruits, it is possible to associate Potamogeton wiesaensis Kirchheimer with the endocarps of the extant species Potamogeton polygonatus Pour (Fig. $4 \mathrm{~F}-\mathrm{H})$ that correspond to later published opinions in agreement with Mai (1999). Knoll (1903) defined Potamogeton natans L. as the living relative of Potamogeton praenatans Knoll and $P$. corolatus Hornem (syn. P. corolatus Vahl.) as the extant descendent of P. stiriacus Knoll. Similarly, Sitár (1969) related the living $P$. corolatus Hornem. to the fossil P. martinianus Sitár. According to Kaplan (personal communication

\begin{tabular}{|c|c|c|c|c|c|}
\hline \multirow{2}{*}{ Taxa } & \multirow{2}{*}{$\mathrm{O}$} & \multicolumn{4}{|c|}{ G } \\
\hline & & $\mathrm{H}$ & $\mathrm{I}$ & $\mathrm{J}$ & $\mathrm{K}$ \\
\hline Myrica integerrima Kräusel \& Weyland & $\mathrm{L}$ & $*$ & & & \\
\hline Myrica lignitum (Ung.) Sap. & $\mathrm{L}$ & & & $*$ & \\
\hline Nyssa bilinica (Ung.) Kvaček & $\mathrm{L}, \mathrm{F}$ & $*$ & $*$ & & \\
\hline Osmunda parschlugiana (Ung.) Andreanszky & $\mathrm{L}$ & $*$ & & & \\
\hline Paliurus tiliaefolius (Ung.) Bůžek & $\mathrm{L}, \mathrm{F}$ & $*$ & & & \\
\hline "Parrotia" pristina (Ettingsh.) Stur sensu Bůžek & $\mathrm{L}$ & $*$ & & & \\
\hline Pinus engelhardtii Menzel & $\mathrm{C}$ & & & $*$ & \\
\hline Pinus sp. & $\mathrm{L}$ & $*$ & & & \\
\hline Pinus urani (Ung.) Schimper & $\mathrm{C}$ & & & $*$ & \\
\hline Poaceae vel Cyperaceae gen. et sp. indet. & $\mathrm{L}$ & $*$ & & & \\
\hline Podocarpium podocarpum (A. Br.) Herendeen & $\mathrm{L}$ & $*$ & & & \\
\hline Populus populina (Bron.) Knobloch & $\mathrm{L}$ & $*$ & & & \\
\hline Populus zaddachii Heer var. brabenecii Teodoridis & $\mathrm{L}$ & $*$ & & & \\
\hline Pronephrium stiriacum (Ung.) Knobloch \& Kvaček & $\mathrm{L}$ & $*$ & & & \\
\hline Pungiphyllum cruciatum (A.Br.) Frankehäuser \& Wilde & $\mathrm{L}$ & $*$ & & & \\
\hline Quasisequoia coutsiae (Heer) Kunzmann & $\mathrm{L}, \mathrm{C}, \mathrm{S}$ & & $*$ & & \\
\hline $\begin{array}{l}\text { Quercus rhenana (Kräusel \& Weyland) Knobloch \& } \\
\text { Kvaček }\end{array}$ & $\mathrm{L}$ & $*$ & & & \\
\hline Rubus merianii (Heer) Kolakovskij & $\mathrm{L}$ & $*$ & & & \\
\hline Salix haidingeri Ettingsh. & $\mathrm{L}, \mathrm{F}$ & $*$ & & & \\
\hline Salvinia reusii Ettingsh. & $\mathrm{L}, \mathrm{Sp}$ & & & & $*$ \\
\hline Schisandra moravica (Mai) Gregor & $\mathrm{S}$ & & & $*$ & \\
\hline Smilax weberi Wessel & $\mathrm{L}$ & $*$ & & & \\
\hline $\begin{array}{l}\text { Spirematospermum wetzleri (Heer) Chandler emend. } \\
\text { Koch \& Friedrich }\end{array}$ & $\mathrm{S}$ & & $*$ & & \\
\hline Stratiotes kaltennordheimensis (Zenker) Keilhack & $\mathrm{S}$ & $*$ & & & \\
\hline Symplocos sp. & $\mathrm{F}$ & & & $*$ & \\
\hline Taxodium dubium (Sternberg) Heer & $\mathrm{C}, \mathrm{L}, \mathrm{S}$ & * & & & \\
\hline Ulmus pyramidalis Goepp. & $\mathrm{L}, \mathrm{F}$ & $*$ & & & \\
\hline "Viburnum" atlanticum Ettingsh. & $\mathrm{L}$ & $*$ & & & \\
\hline Vitis teutonica $\mathrm{A} . \mathrm{Br}$. & S & $*$ & & & \\
\hline Zelkova zelkovifolia (Ung.) Bůžek \& Kotlaba & $\mathrm{L}$ & $*$ & & & \\
\hline
\end{tabular}

2006), the leaf described herein matches better the extant $P$. nodosus Poir. (Fig. 4I, J) with smaller leaves than P. natans, $P$. coloratus and $P$. polygonatus.

\section{Palaeoecological interpretation}

The Potamogeton remains occurred in two genetically different environments. The first one is a deltaic environment (system of the Bílina Delta), which is documented by the leaf from the Bílina Mine (horizon No. 1). The second type is a basin environment characterized by coal and coalclayey lithofacies including the studied fruits from the cores of MR 59/48-50 m, KU 115/97-98 m and the NástupTušimice Mine. According to the autecology of the modern species of Potamogeton L., the fossils belong to the aquatic vegetation within coal-forming biotopes and also the reed vegetation associated within riparian settings. The aquatic vegetation corresponds to Salvinia reussii association sensu Kvaček \& Bůžek (1982, p. 20), which includes together with Potamogeton other aquatic free-floating elements such as Salvinia reussii Ettingsh. (E1), Azolla sp. (E1), Hemitrapa heissigii Gregor (E1), Stratiotes kaltennordheimen- 
sis (Zenker) Keilhack / S. schaarschmidtii Kvaček (E1), Lemna cestmiri Kvaček (E1), Limnobiophyllum expansum (Heer) Kvaček, (E1) Hydrochariphyllum buzekii Kvaček (E1) and Elephantosotis dvorakii Kvaček (E1). This vegetation can simply pass distal parts to reeds and then into coniferous swamp forest or mixed swamp forest association - Teodoridis (2004, pp. 134-136). The association of reeds contains other rooted "aquatic" elements, i.e. Poaceae vel Cyperaceae (E1), Decodon gibbosus (E2), Sparganium spp. (E1), Proserpinaca reticulata C et E.M. Reid (E1); and helophytes elements such as Spirematospermum wetzleri and Zingiberoideophyllum liblarense (E2), Pronephrium stiriacum (E2), Calamus daemonorhops (Unger) Chandler (E2) and Sabal sp. (E2). According to Kvaček (1998), the accumulation of Salix haidingerii Ettingsh., well known from delta deposits in Bílina and Hrabák (the Žatec Delta), can be interpreted as periodically flooded, pioneer, monotonous growths that also occurred in association with a rich aquatic vegetation of the horizons No. 21 and No. 47 (Kvaček 2003). The associated flora of the Nástup-Tušimice Mine shows elements that correspond to the association of coniferous swamp forest (Glyptostrobus association sensu Kvaček \& Bůžek 1982). The associated flora of horizon No. 1 also contains typical elements of the mixed swamp forest (Nyssa-Taxodium association sensu Kvaček \& Bůžek 1982) in combination with riparian and mesophytic elements (Parrotia-Ulmus pyramidalis association sensu Kvaček \& Bůžek 1982).

\section{Acknowledgments}

I am thankful to Z. Kvaček, Z. Kaplan and J. Eder for helpful discussions and B. Meller, E. Martinetto and J. Sakala for useful comments to the first version of the manuscript. I am grateful to J. Kvaček, Z. Dvořák, O. Janeček and J. Dykast for the access to the original fossil material in the collection of the National Museum in Prague, the collection of the SD a. s. (Doly Bílina, Doly Nástup-Tušimice) and the collection of the Regional Museum in Most. Also I would like to thank all the people who provided me with comparative extant material, namely J. Hadinec (Herbarium of the Charles University, Prague), Z. Kaplan (Herbarium of the National Museum, Průhonice) and E. Zastawniak (W. Szafer Institute of Botany, Polish Academy of Sciences, Krakow), and helped me with the SEM manipulation, namely M. Mazuch. Special thanks go to my wife. The study was supported by the grant GAČR (Grant Agency of the Czech Republic) No. 205/06/P007.

\section{References}

BRABENEC, B. 1909. Souborná květena českého útvaru třetihorního. Archív pro př́rodovědecké prozkoumání Čech 19(3), 1-144.

BŮŽEK, Č. \& HOLÝ, F. 1964. Small-sized plants remains from the Coal Formation of the Chomutov-Most-Teplice Basin. Sborník geologických věd, Paleontologie 4, 105-138.
BƯŽEK, Č., HolÝ, F. \& KVAČEK, Z. 1976. Tertiary flora from the Volcanogenic series at Markvartice and Veselíčko near Česká Kamenice (České Středohoří Mts.). Sborník geologických věd, Paleontologie 18, 69-132.

BƯŽEK, Č., DVOŘÁK, Z., KVAČEK, Z. \& PROKEŠ, M. 1992. Tertiary vegetation and depositional environments of the Bílina delta in the North Bohemian brown coal basin. Časopis pro mineralogii a geologii 37(2), 117-134.

Collinson, M. 1982. A reassessment of fossil Potamogetoneae fruits with description of new material from Saudi Arabia. Tertiary Research 4(3), 83-104.

CZAJA, A. 2003. Paläokarpologische Untersuchungen von Taphozönosen des Unter- und Mittelmiozäns aus dem Braunkohlentagebau Berzdorf/Oberlausitz (Sachsen). Palaeontographica B $265,1-148$.

DOMÁCÍ, L. 1977. Litostratigrafie třetihorních sedimentů v hnědouhelné severočeské pánvi. Acta Universitatis Carololinae, Geologica 1975(1), 75-80.

DoROFEEV, P.I. 1963. Tretitchnye flory Zapadnoj Sibiri. 345 pp. Izd. akad. nauk SSR, Moskva - Leningrad.

DOROFEEV, P.I. 1977. K sistematike neogenovych Potamogeton Belorussii. Doklady Akademie nauk BSSR 21(8), 736-738.

ElZNIC, A. 1973. Sedimenty neogénu a vývoj uhelné sloje v mostecké části severočeské pánve. Věstník Ústředního ústavu geologického 24, 175-204.

FRIIS, E.M. 1985. Angiosperm fruits and Seed from the Midle Miocene of Jutland (Denmark). Det Kongelige Danske Videnskaberne Selskab Biologiske Skrifter 24(3), 1-165.

GREGOR, H.J. 1982. Die Jungtertiären Floren Süddeutschlands. Paläokarpologie, Phytostratigraphie, Paläoökologie, Paläoklimatologie. 278 pp. Ferdinand Enke, Stuttgart.

HAYNeS, R.R. \& HellQuist, C.B. 2000. Potamogetonaceae, 47-74. In FLORA OF NORTH AMERICA EDITORIAL COMMITTEE (eds) Flora of North America North of Mexico, Vol. 22. Oxford University Press, New York and Oxford.

HAYNES, R.R., LES, D.H. \& Holm-NIELSEN, L.B. 1998. Potamogetonaceae, 408-415. In KUBITZKI, K. (ed.) Flowering Plants. Monocotyledons Alismatanae and Commelinanae (except Gramineae). The Families and Genera of Vascular Plants, Vol. 4. Springer-Verlag, London.

HEER, O. 1855. Flora tertiaria Helvetiae. Vol. 3. 118 pp. J. Wurster \& Co., Winterhur.

HoLÝ, F. 1974. Neogénní mastixioidní květena svrchního slojového pásma z lomu Kristina (Hrádek n. N.). 131 pp. PhD thesis, Charles University, Prague, Czech Republic.

HOLÝ, F. 1976. The assemblage of autochthonous coal plant-remains from the Miocene near Hrádek nad Nisou (Zittau Basin, North Bohemia). Acta Musei Nationalis Pragae, Series B - Historia Naturalis 32(1), 1-13.

HURNík, S. \& KNOBLOCH, E. 1966. Einige Ergebinsse paläontologischer und stratigraphischer Untersuchungen im Tertiär Böhmens. Abhandlungen des Staatlichen Museums für Mineralogie und Geologie zu Dresden 11, 17-161.

JiROTKA, P. 1976. Dílčí zpráva. Hydrogeologické zpracování vrtů PVJK-202/KU 113, PVJK-203/KU 114, HVJK-204/KU 115. 43 pp. Geofond (GF V075528), Prague, Czech Republic.

KIRCHHEIMER, F. 1942. Zur Kenntnis der Alttertiärflora von Wiesa (Sachsen). Planta 32, 418-446.

KIRCHHEIMER, F. 1957. Die Laubgewächse der Braunkohlenzeit. 783 pp. VEB Wilhelm Knapp Verlag, Halle (Saale). 
KNOBLOCH, E. 1969a. Tertiäre Floren von Mähren. 201 pp. Moravské museum Brno, Brno.

KNOBLOCH, E. 1969b. Nové rostlinné nálezy z panonu v severní části vídeňské pánve. Zprávy o geologických výzkumech v roce 1968, 230-232.

KNOBLOCH, E. 1977. Fossile Potamogeton-Funde aus dem tschechoslowakischen Jungtertiär und Altquartär. Časopis pro mineralogii a geologii 22(1), 29-42.

KNOLL, F. 1903. Zwei tertiäre Potamogeton Arten aus der Section Heterophylli Koch. Österreichische Botanische Zeitschrift 53(7), 270-275.

Kovar-EGER, J. \& KRAINER, B. 1991. Flora und Sedimentologie der Fundstelle Reih bei Unterstorcha, Bezirk Feldbach in der Steiermark (Kirchberger Schotter, Pannonium C, Miozän). Jahrbuch der Geologische Bundesanstalt 134(4), 737-771.

KVAČEK, Z. 1998. Bílina: a window on Early Miocene marshland environments. Review of Palaeobotany and Palynology 101(1998), $111-123$.

KVAČEK, Z. 2003. Aquatic Angiosperms of the Early Miocene Most Formation of the North Bohemia (Central Europe). Courier Forschungsinsitut Senckenberg 241, 255-279.

KVAČEK, Z. 2006. Excursion B3, Day 1, stop 1 - Opencast Mine Nástup Tušimice, 66-69. In FATKA, O. \& KVAČEK, J. (eds) Excursions guide book, $7^{\text {th }}$ European Palaeobotany-Palynology Conference, Prague. National Museum, Prague.

KVAČEK, Z. \& BƯŽEK, Č. 1982. Třetihorní společenstva severočeské hnědouhelné pánve ve vztahu k litofaciálnímu vývoji. 46 pp. Ústav Geologie a Geotechniky ČSAV, Prague, Czech Republic (unpublished report).

KvaČEK, Z., BÖHME, M., Dvoř́́K, Z., KonZalovÁ, M., MACH, K. PROKOP, J. \& RAJCHL, M. 2004. Early Miocene freshwater and swamp ecosystems of the Most Basin (north Bohemia) with particular reference to the Bílina Mine section. Journal of the Czech Geological Society 49(1-2), 1-40.

LES, D.H. \& HAYNES, R.R. 1995. Systematic of subclass Alismatidae: synthesis of approaches, 353-377. In RUNDAL, P.J., CRIBB, P.J., CUTLER, D.F. \& HUMPHRIES, C.J. (eds) Monocotyledons: systematics and evolution. Royal Botanic Gardens, Kew.

LES, D.H. \& HAYNES, R.R. 1996. Coleogeton (Potamogetonaceae), a new genus of pondweeds. Novon 6, 389-391.

MACH, K. 2002. Anomální stavba hlavni hnědouhelné sloje v prostoru miocénní bílinské delty a jejich geneze. $85 \mathrm{pp}$. $\mathrm{PhD}$ thesis, Charles University, Prague, Czech Republic.

MAI, D.H. 1960. Über neue Früchte und Samen aus dem deutschen Tertiär. Paläontologische Zeitschrift 34, 73-90.

MAI, D.H. 1987. Neue Arten nach Früchten und Samen aus dem Tertiär von Nordwestsachsen und der Lausitz. Feddes Repertorium 98(1-2), 105-126.

MAI, D.H. 1999. Die untermiozänen Floren aus der Spremberger Folge und dem 2. Flözhorizont in der Lausitz Teil I. Farnpflanzen, Koniferen und Monokotyledonen. Palaeontographica B 250(1-3), 1-76.

MAI, D.H. 2000. Die mittelmiozänen und obermiozänen Floren aus der Meuroer und Raunoer Folge in der Lausitz Teil I. Farnpflanzen, Koniferen und Monokotyledonen. Palaeontographica B 256, 1-68.
MALKovskÝ, M., BrunerovÁ, Z., BỦŽEK, Č., ČADEK, J., ČADKOVÁ, Z., ČECH, F., ČUTA, J., DOMÁCí, L., ElZNIC, A., FEJFAR, O., Gabriel, M., GabrielovÁ, N., HerCogovÁ, J., HOKR, Z., KaČURA, G., KOdYMOVÁ, A., KOPECKÝ, L., KrÁlík, F., Kurendová, J., Líbalová, J., Malecha, A., Manová, M., MaŠín, J., PlZÁK, V., RÁKosovÁ, M., ŘEHÁKOVÁ, Z., SCHOVÁNeK, P., SchovÁnKovÁ, D., ŠalanskÝ, K., ŠEbesta, J., ŠMEJKAL, V., ŠRÁMEK, J., ŠTEMPROK, M., TÁSLER, R., TYRÁČEK, J. \& URBAN, J. 1985. Geologie severočeské hnědouhelné pánve a jejího okolí. 424 pp. Vydavatelství ČSAV, Praha.

NĚMEJC, F. 1967. Paleofloristické studie v neogénu Slovenska. Acta Musei nationalis Pragae, Series B - historia naturalis 23(1), $1-32$.

OBERHELOVÁ, N. 1983. Rybí společenstva nadloži až podloží severočeské hnědouhelné pánve a jejich přeměny. $60 \mathrm{pp}$. Ústav geologie a geotechniky ČSAV, Prague, Czech Republic (unpublished report).

RAJCHL, M. \& ULIČNÝ, D. 2005. Depositional record of an avulsive fluvial system controlled by peat compaction (Neogene, Most basin, Czech Reoublic). Sedimentology 52, 601-625.

ReID, C. \& REID, E.M. 1910. The lignite of Bovey Tracey. Philosophical Transactions of the Royal Society of London, Series B 201, 161-178.

SITÁR, V. 1969. Die Paläoflora des Turiec-Beckens und ihre Beziehung zu den Mitteleuropäischen Floren. Acta geologica et geographica Universitatis Comenianae, Geologica 17, 99-174.

StEARN, W.T. 2004. Botanical Latin. 546 pp. Timber Press, Bath, UK.

STIZENBERGER, E. 1851. Übersicht der Versteinerungen des Grossherzogthums Baden. 144 pp. Freiburg in Breisgau.

TEODORIDIS, V. 2003. Early Miocene carpological material from the Czech part of the Zittau Basin. Acta Palaeobotanica 43(1), 9-49.

TEODORIDIS, V. 2004. Floras and vegetation of Tertiary fluvial sediments of Central and Northern Bohemia and their equivalents in deposits of the Most Basin (Czech Republic). Acta Musei nationalis Pragae, Series B - historia naturalis 60(3-4), 113-142.

TEODORIDIS, V. 2005. Revision of the Early Miocene seed of Schisandra moravica (Mai in Knobloch) Gregor from the Czech Republic. Neues Jahrbuch für Geologie und Paläontologie, Abhandlungen 2005(11), 663-682.

TEODORIDIS, V. \& KVAČEK, Z. 2006. Complex palaeobotanical research of deposits overlying the main coal seam (Libkovice and Lom Mbs.) in the Most Basin (Czech Republic). Bulletin of Geosciences 81(2), 93-113.

VÁCL, J. \& MALKOVSKÝ, M. 1962. Geologie Žatecka (Geologie des Saatzer Gebietes). Sborník Ústředního ústavu geologického, Geologie 27, 291-330.

VÁNĚ, M. 1985. Geologické poměry neogénních hlavačovských štěrkopísků mezi Rakovníkem a Holedečí. Sborník Severočeského muzea, Přírodní vědy 14, 205-218.

VelichKeVICH, F.Y. \& LeSIAK, M.A. 1996. Fossil Potamogeton species of Mizerna. Acta Palaeobotanica 36(1), 79-95.

ZASTAWNIAK, E. 1980. Sarmatian leaf flora from the southern margin of the Holy Cross Mts. (South Poland). Prace Muzeum Ziemi 33, 39-107. 